\title{
Electron Transport Carriers Involved in Nitrogen Fixation by the Coliform, Klebsiella pneumoniae
}

\author{
By D. C. YOCH \\ Department of Cell Physiology, University of California, \\ Berkeley CA 94720, U.S.A.
}

(Received 2 January 1974; revised I8 February 1974)

\begin{abstract}
SUMMARY
In cell-free extracts, pyruvate, formate, malate and NADPH provided reducing equivalents to the nitrogenase of the nitrogen-fixing colform, Klebsiella pneumoniae. Two electron carriers were isolated from extracts, both capable of mediating the transfer of reducing power between illuminated spinach chloroplasts and the nitrogenases of Klebsiella or Azotobacter vinelandii. One electron carrier was a flavoprotein, named Klebsiella flavodoxin (molecular weight about 2 I000); the second was not characterized. A similarity is suggested between Klebsiella and Escherichia coli in the generation and transport of low-potential reducing power from pyruvate.
\end{abstract}

\section{INTRODUCTION}

Klebsiella pneumoniae* is a coliform bacterium that is capable of nitrogen fixation under anaerobic (Hamilton \& Wilson, I955) or microaerophilic (Klucas, 1972) conditions and is commonly isolated from plant and soil sources (Silver, Centifanto \& Nicholas, 1963; Pengra, 1964; Mahl, Wilson, Fife \& Ewing, 1965). The metabolism (Hamilton \& Wilson, I955) and'genetic make-up (Matsumoto \& Tazaki, I970; Streicher, Gurney \& Valentine, 197I; Dixon \& Postgate, 197I, 1972) of K. pneumoniae show it to be closely related to Escherichia coli. Although the nitrogenase of Klebsiella has been studied extensively by Biggins \& Kelly (1970) and Eady, Smith, Cook \& Postgate (1972), little is known of the electron transport pathway that couples the oxidation of substrate to the reduction of the nitrogenase enzyme. In other nitrogen-fixing organisms, ferredoxins and flavodoxins transfer highly reducing electrons to nitrogenase (see review by Burris, 1971). Sodium dithionite (Mahl \& Wilson, 1968) or hydrogenase-reduced methyl viologen (Eady et al. 1972) (both non-physiological reductants) have until now been the only reductants found to provide reducing power for nitrogen fixation in cell-free extracts of Klebsiella.

An artificial reductant which has proven useful in elucidating the electron transport systems of Chromatium (Yoch \& Arnon, 1970), Azotobacter vinelandii (Benemann, Yoch, Valentine \& Arnon, 1969; Yoch, Benemann, Valentine \& Arnon, 1969), soybean root nodule bacteroids (Yoch et al. 1970; Koch et al. 1970) and Bacillus polymyxa (Yoch, 1973), is illuminated chloroplasts. Unlike dithionite, which reduces the nitrogenase directly (Bulen, Burns \& LeComte, 1965), chloroplasts reduce nitrogenase only through intermediate low-potential electron carriers such as ferredoxin (Fd) or flavodoxin (Fld) (reaction I).

$$
\text { Reduced dye } \underset{\text { chlumphats }}{\stackrel{\text { h }}{\longrightarrow}} \text { Fd or Fld } \longrightarrow \text { nitrogenase }
$$

* On the basis of serological and biochemical tests, Mahl, Wilson, Fife \& Ewing ( 1965 ) reclassified various nitrogen-fixing strains of Klebsiella, Aerobacter aerogenes and Achromobacter as Klebsiella pneumoniae. 
This 'chloroplast-nitrogenase' technique has now been used to identify in Klebsiella two electron transport components capable of transferring low-potential reducing power to the nitrogenase system.

In addition to reporting the partial purification and biochemical activities of the two low-potential electron transport components from Klebsiella, this paper reports the physiological substrates that are capable of providing reducing power of Klebsiella nitrogenase in cell-free extracts and the activity of $E$. coli flavodoxin and a pyruvate dehydrogenase system from $E$. coli in coupling to Klebsiella nitrogenase.

\section{METHODS}

Preparation of bacterial extracts. Klebsiella pneumoniae strain M5al, provided by P. W. Wilson from the culture collection of the University of Wisconsin, was cultured in I 21 carboys on a mineral salts medium as described by Yoch \& Pengra (1966). Nitrogen was provided by sparging the culture with nitrogen gas. Klebsiella extracts were prepared by disrupting frozen cell paste in a Hughes press (other methods of cell disruption proved to be less satisfactory, especially for pyruvate- and formate-supported nitrogenase activity). The resulting frozen extract was thawed in I vol. $0.02 \mathrm{M}-N-2$-hydroxyethylpiperazine- $N^{\prime}-2-$ ethane sulphonic acid (HEPES) buffer, $\mathrm{pH} \mathrm{7*4}$, plus I $\mathrm{mg}$ deoxyribonuclease under an atmosphere of argon. After incubation with deoxyribonuclease for $30 \mathrm{~min}$ at room temperature, the extract was centrifuged at $35000 \mathrm{~g}$ for $\mathrm{I} 5 \mathrm{~min}$ and the supernatant was retained as the Klebsiella nitrogenase extract. When the extract was stored under an atmosphere of argon at $-20^{\circ} \mathrm{C}$, dithionite-supported nitrogenase activity was stable (that is, it retained more than $50 \%$ of its original activity) for 8 to ro months.

The endogenous electron carriers were removed by passing Klebsiella extracts (approx. Io $\mathrm{ml}$ portions) that had been stored at $-20{ }^{\circ} \mathrm{C}$ for a month or more over a $2 \times 3 \mathrm{~cm}$ DEAEcellulose column which had previously been equilibrated with argon-saturated $0.02 \mathrm{M}$ -

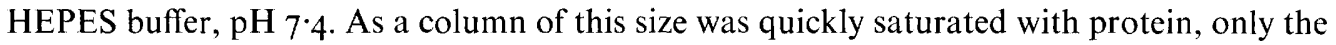
more acidic proteins, such as the Klebsiella electron carriers, were bound to the DEAEcellulose column. The more weakly acidic nitrogenase proteins were not retained by the column and were recovered in the effluent (as measured by $\mathrm{C}_{2} \mathrm{H}_{2}$-reducing activity, over $90 \%$ of the nitrogenase passed through the column). After washing the DEAE-cellulose column with 10 to $15 \mathrm{ml}$ HEPES buffer, the electron carriers were eluted with buffer containing $0.8 \mathrm{M}-\mathrm{NaCl}$. For washing the column and eluting the electron carriers, anaerobic precautions were not necessary as these carriers were stable in air.

Repeated freeze-thaw cycles and various detergent treatments were tried, but only prolonged freezing followed by DEAE-cellulose treatment removed the electron carriers to the extent that the nitrogenase could be used to assay the isolated electron carriers in the chloroplast-nitrogenase system (reaction I). Because the period of freezing could not be standardized, not all extracts frozen and treated on DEAE-cellulose could be used to assay for electron carriers. A dilemma arises in that methods and reagents drastic enough to release the electron carriers also destroy the nitrogenase. The prolonged freezing of the Klebsiella extract is the only known method that will release the electron carriers while leaving a functional nitrogenase enzyme.

Azotobacter vinelandii was cultured, harvested and disrupted as previously described by Benemann et al. (I969). Nitrogenase extracts were prepared and the endogenous electron carriers were removed by treatment on a DEAE-cellulose column as previously described by Benemann, Yoch, Valentine \& Arnon (1971). 
Escherichia coli, Crookes strain, was cultured anaerobically on L-broth (a glucose-yeast extract-tryptone medium) described by Luria \& Burrous (1957). Frozen cells were disrupted in a Hughes press as described above for Klebsiella. The supernatant extract (35000 $\mathrm{g}$ for $10 \mathrm{~min}$ ) was stored under argon and used within several hours of preparation.

Purification of the Klebsiella electron carriers. To purify the electron carrier component from nitrogen-grown Klebsiella cells, $500 \mathrm{~g}$ cell paste was suspended in 2 vol. $0.02 \mathrm{M}$-phosphate buffer, $\mathrm{pH} 7 \cdot 4$ (hereafter referred to as the buffer). The cell suspension was sonicated for 5 min with a $20 \mathrm{kHz}$ Branson sonifier at full power. The extract was brought to $30 \%(\mathrm{v} / \mathrm{v})$ with cold $\left(-20^{\circ} \mathrm{C}\right) n$-butanol and was constantly stirred for 30 min at $5{ }^{\circ} \mathrm{C}$. The butanol extract was centrifuged for $30 \mathrm{~min}$ at $10000 \mathrm{~g}$ and the resulting butanol-containing supernatant solution was passed over a DEAE-cellulose column. After the column was washed with several volumes of buffer, the yellowish-brown band that had collected at the top of the column was eluted with buffer containing $0.5 \mathrm{M}-\mathrm{NaCl}$ and dialysed against buffer overnight. This solution was placed on a DEAE-cellulose chromatography column ( $1 \cdot 5 \times 45$ $\mathrm{cm})$ previously equilibrated with buffer. The column was developed with $150 \mathrm{ml}$ buffer containing $0.1 \mathrm{M}-\mathrm{NaCl}$, followed by buffer containing $0.2 \mathrm{M}-$ and then $0.32 \mathrm{M}-\mathrm{NaCl}$. Four coloured bands eluted from this column; each was further purified by Sephadex G-50 column chromatography. The characterization and biological activities of these fractions are discussed in Results.

Assay of enzymic activities. The Klebsiella electron carrier fractions were assayed for their ability to mediate electron transport between illuminated spinach chloroplast fragments (prepared as described by Yoch, 1972) and either Klebsiella or Azotobacter nitrogenase. The conditions of the assay and the content of the reaction mixture are described in the legend to Fig. I. Nitrogenase activity was measured by the reduction of acetylene to ethylene (Schöllhorn \& Burris, 1966; Dilworth, 1966) as determined by gas chromatography (Hardy, Holsten, Jackson \& Burns, 1968).

The Klebsiella electron carriers were also assayed for their ability to substitute for plant ferredoxin in the photochemical reduction of $\mathrm{NADP}^{+}$using either heated $\left(55^{\circ} \mathrm{C}, 5 \mathrm{~min}\right)$ washed chloroplasts or blue-green algae particles. The reaction mixture was that described for Fig. I of Yoch et al. (1969). The details of light source, filters, and geometry of the system for continuous monitoring of $\mathrm{NADP}^{+}$reduction were described by McSwain \& Arnon (1968).

Electron carriers. Escherichia coli flavodoxin, a gift of J. Knappe, was prepared according to Vetter \& Knappe (1971). Azotoflavin from A. vinelandii was prepared as described by Benemann et al. (1969).

\section{RESULTS}

\section{Klebsiella nitrogenase activity}

Pyruvate and formate, both key intermediates in the anaerobic metabolism of glucose by coliform bacteria (Wood, I96I), provide reducing equivalents for nitrogen fixation when supplied to crude nitrogenase extracts of Klebsiella pneumoniae (Table I). The rate of nitrogenase activity supported by formate varied; in some experiments the rate was equal to that with pyruvate, while in other experiments the rates were very low. The reducing power of malate and NADPH (NADH was not tested) could also be coupled to the Klebsiella nitrogenase system. While the dithionite-supported activity appears to be quite low (Eady et al. 1972), the protein concentration used in this experiment was optimized for the pyruvate- and formate-supported and not the dithionite-supported nitrogenase activity. The high concentration of crude extract protein used in this experiment $(10 \mathrm{mg})$ 


\section{Table I. Sources of reducing power for $K$. pneumonicie nitrogenase}

The reaction mixture (final volume, $1.5 \mathrm{ml}$ ) contained $\mathrm{I} 0 \mathrm{mg} K$. pneumoniae extract and the following (in $\mu \mathrm{mol}$ ): HEPES buffer $(\mathrm{pH} \mathrm{7.4}), 50 ; \mathrm{MgCl}_{2}, 5$; creatine phosphate, 40; ATP, 4; creatine phosphokinase, $0.005 \mathrm{mg}$; and electron donor substrates as indicated. Gas phase, argon $73 \%$ and acetylene $27 \%$, reaction time, Io $\mathrm{min}$; temperature, $30 \mathrm{C}$.

$$
\begin{gathered}
\text { Ethylene formed } \\
\text { (nmol/min) }
\end{gathered}
$$

$\begin{array}{lr}\text { None } & 3 \cdot 7 \\ \text { Pyruvate }(67 \mathrm{~mm}) & 58 \cdot 5 \\ \text { Formate }(67 \mathrm{~mm}) & 20.6 \\ \text { Malate }(67 \mathrm{~mm}) & 16.0 \\ \text { NADPH generating system* } & 15 \cdot 3 \\ \text { Dithionite (I3 mM) } & 57 \cdot 0\end{array}$

* See Benemann et al. (1971) for details.

was probably too high (and consequently inhibitory) for optimum rates of dithionitesupported nitrogenase activity, since in other experiments rates ranging between 180 and $345 \mathrm{nmol}$ ethylene formed/min have been observed for dithionite-supported nitrogenase activity when about half this amount of protein was used.

Dithionite-, pyruvate- and formate-supported nitrogenase activity in fresh extracts was linear for about $15 \mathrm{~min}$; the same was assumed for malate- and NADPH-supported activity. The addition of creatine phosphate to the reaction mixture (anaerobically with a syringe) after $15 \mathrm{~min}$ brought the nitrogenase activity back to its original linear rate. This observation indicates that the fresh Klebsiella extracts have extremely active ATPase activities. After several days of storage of the extract at $-20{ }^{\circ} \mathrm{C}$, the nitrogenase activity was linear for at least $30 \mathrm{~min}$.

Evidence which may suggest a similarity between Klebsiella and E. coli in the generation and transport of low-potential electrons is shown in Table 2 and Fig. I. Pyruvate-supported nitrogenase activity in 4-day-old Klebsiella extracts is approximately one-tenth the level of that in fresh extracts. The low level of pyruvate-supported nitrogenase activity was stimulated fivefold by the addition of extract from $E$. coli grown anaerobically on glucose (Table 2). It appears that E. coli extract replaced the component(s) of the Klebsiella pyruvate 'hydrogen-donating system' that was inactivated with age, thereby restoring the pyruvate-

\section{Table 2. Effect of E. coli extract in coupling pyruvate-supported nitrogenase activity in a Klebsiella extract}

Reaction mixture as in Table I except that the Klebsiella nitrogenase extract (10 mg protein) was 4 days old and had low pyruvate-supported nitrogenase activity and $E$. coli extract was added as indicated. The pyruvate-supported nitrogenase activity of the freshly prepared extract (same protein concentration) was $60.8 \mathrm{nmol}$ ethylene formed $/ \mathrm{min}$. A control showed that the dithionitesupported nitrogenase activity of this 4-day-old Klebsiella extract was unimpaired. Reaction time, $20 \mathrm{~min}$.

$\begin{array}{cc}\begin{array}{c}\text { E. coli } \\ \text { extract added } \\ (\mathrm{mg})\end{array} & \begin{array}{c}\text { Klebsiella nitrogenase } \\ \text { activity (ethylene } \\ \text { formed, nmol/min) }\end{array} \\ 0.0 & 6.5 \\ \mathrm{I} \cdot 9 & 14.6 \\ 3.8 & 17.4 \\ 7.6 & 25.2 \\ \mathrm{I} 1 \cdot 4 & 3 \mathrm{I} \cdot \mathrm{I}\end{array}$


supported nitrogenase activity of the Klebsiella extract. No attempt was made to replace the $E$. coli extract with $K$. pneumoniae flavodoxin.

One component from $E$. coli extract that is capable of functioning in the Klebsiella nitrogenase system is the flavodoxin (Fig. I). Furthermore, E. coli flavodoxin appeared to couple electron flow to the nitrogenase of the coliform Klebsiella more efficiently than to the nitrogenase of a noncoliform, $A$. vinelandii. The two nitrogenase extracts had previously been treated on a DEAE-cellulose column to remove the endogenous electron carriers, and the protein concentrations were then adjusted so that both had equal dithionite-supported nitrogenase activity. When the reducing power of illuminated chloroplasts was coupled to the respective nitrogenases by equal concentrations of $E$. coli flavodoxin, the rate of Klebsiella nitrogenase activity was more than double that of Azotobacter nitrogenase.

\section{Isolation of Klebsiella electron carriers}

The Klebsiella nitrogenase system is unlike that of $A$. vinelandii, B. polymyxa or Rhizobium root nodule bacteriods in that the reducing power of illuminated chloroplasts cannot

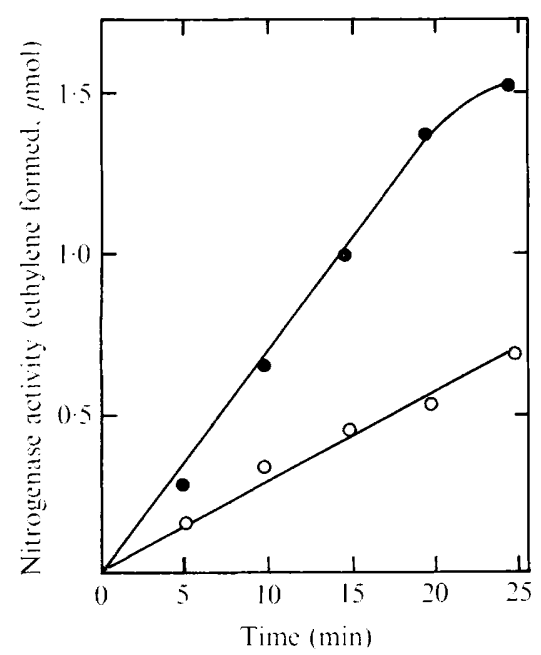

Fig. I. Comparison of ability of $(\bullet) K$. pneumoniae and $(O) A$. vinelandii nitrogenases to couple to photoreduced $E$. coli flavodoxin. Either $K$. pneumoniae or $A$. vinelandii nitrogenase, $0 . \mathrm{I} \mathrm{ml}$, and $E$. coli flavodoxin, $0.02 \mu \mathrm{mol}$, were added to a reaction mixture (final volume, $1.5 \mathrm{ml}$ ) containing washed ferredoxin-free spinach chloroplasts $(0.3 \mathrm{mg}$ chlorophyll), and the following (in $\mu \mathrm{mol})$ : ascorbate, 10; 2,6-dichlorophenol indophenol (DPIP) (ascorbate-reduced DPIP replaced water as a source of electrons in the chloroplast fragments), 0.05 ; HEPES buffer $(\mathrm{pH} 7 \cdot 4), 50 ; \mathrm{Mg}^{++1}$, 5; creatine phosphate, 40; ATP, 4; and creatine phosphokinase, $0.005 \mathrm{mg}$. Light intensity, saturating: gas phase and temperature as in Table $\mathrm{I}$; reaction time, 20 min.

be coupled to a freshly prepared nitrogenase extract without the addition of soluble ferredoxin. Only after prolonged freezing of the Klebsiella extracts could electrons from illuminated chloroplasts be coupled to the nitrogenase (Table 3). Treatment of these nitrogenase extracts on a DEAE-cellulose column removed a factor that was essential for chloroplast-supported nitrogenase activity. Because the extract that passed through the DEAE-cellulose column still had high rates of dithionite-supported nitrogenase activity, it was assumed that DEAE-cellulose had removed an electron carrier component that was 


\section{Table 3. Chloroplast-linked Klebsiella nitrogenase activity}

The reaction mixture and conditions of assay were similar to those described in Fig. I [with the source of reducing power for the nitrogenase reaction being washed (ferredoxin-free) spinach chloroplasts $(0.3 \mathrm{mg}$ chlorophyll)]. A $0.2 \mathrm{ml}$ sample (approx. 6. I mg protein) of Klebsiella nitrogenase extract was assayed after each successive treatment.

\section{Treatment of extract}

Ethylene formed (nmol/min)

None (freshly prepared extract)

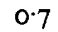

$-20{ }^{\circ} \mathrm{C}, 24$ days

$-20{ }^{\circ} \mathrm{C}, 38$ days

DEAE-cellulose treated

DEAE-cellulose treated extract $+0.1 \mathrm{ml}$ DEAE-cellulose eluate*

24.0
33.7
6.3
30.6

* The electron carrier fraction was eluted from the DEAE-cellulose column with $0.02 \mathrm{M}-\mathrm{HEPES}$ buffer, $\mathrm{pH} 7 \cdot 4$, containing $0.8 \mathrm{M}-\mathrm{NaCl}$.

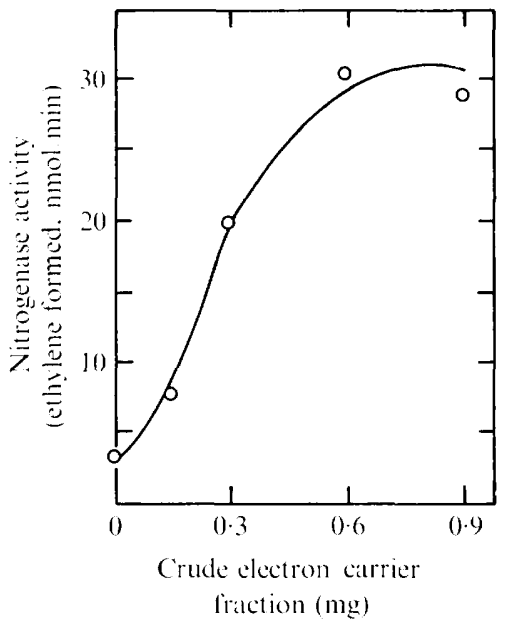

Fig. 2

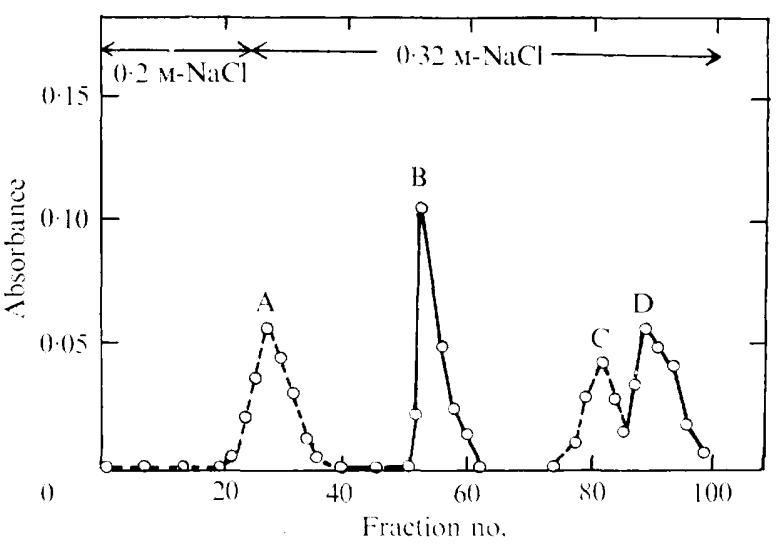

Fig. 3

Fig. 2. Effectiveness of a Klebsiella DEAE-cellulose eluate in coupling electrons between illuminated chloroplasts and Klebsiella nitrogenase. Reaction time and mixture as in Fig. I with Klebsiella nitrogenase, $6.5 \mathrm{mg}$, and Klebsiella DEAE-cellulose eluate electron carrier fraction as indicated.

Fig. 3. Chromatography of Klebsiella electron carriers on DEAE-cellulose. Before collection of $4.5 \mathrm{ml}$ fractions, the column was eluted with $150 \mathrm{ml}$ phosphate buffer $(\mathrm{pH} 7 \cdot 3)$ containing $0 \cdot \mathrm{I}_{\mathrm{M}-\mathrm{NaCl}}$. This was followed with buffer containing $\mathrm{NaCl}$ as indicated. The profile of fractions $\mathrm{A}$ and $\mathrm{B}$ was determined by absorbance at $450 \mathrm{~nm}$, of fraction $C$ at $630 \mathrm{~nm}$, and of fraction D at $460 \mathrm{~nm}$. $0-\cdots$, Biologically active fractions; $0_{-}-0$, biologically inactive fractions.

essential in coupling electron flow between the chloroplasts and nitrogenase. Addition of this crude electron carrier fraction back to the DEAE-cellulose treated Klebsiella extract restored the chloroplast-supported nitrogenase activity, the degree of restoration being dependent on the concentration of the electron carrier fraction (Fig. 2).

The Klebsiella electron carriers were purified from a butanol extract on a DEAE-cellulose chromatography column eluted with buffer containing increasing concentrations of $\mathrm{NaCl}$. The resulting elution pattern of coloured proteins (designated fractions A, B, C and D) and the salt concentrations required for their elution are shown in Fig. 3. The dashed line indicates those protein fractions with no biological activity; the solid line (fractions 


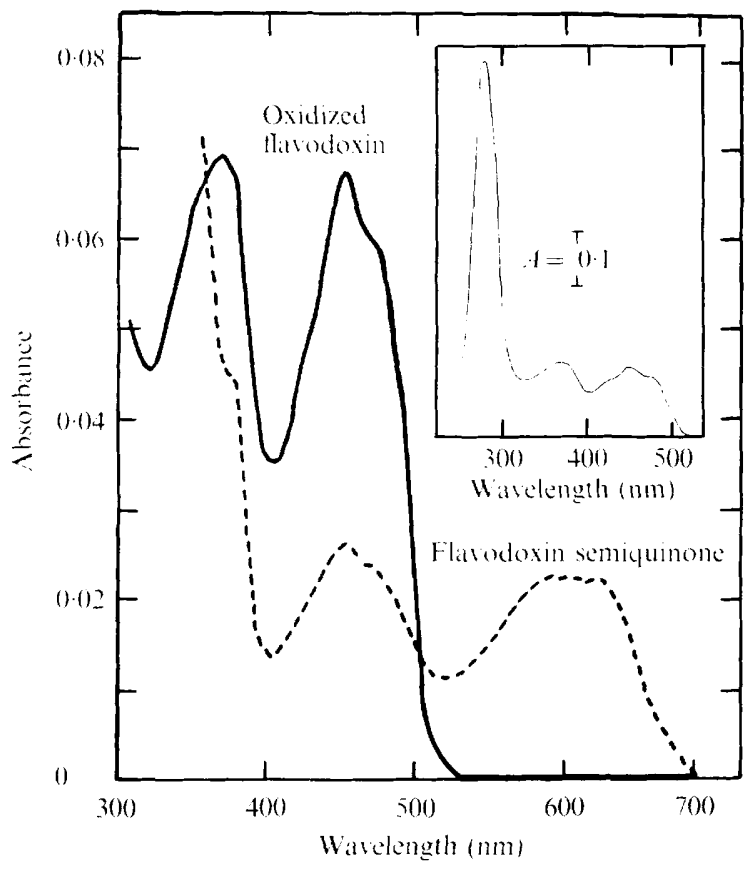

Fig. 4

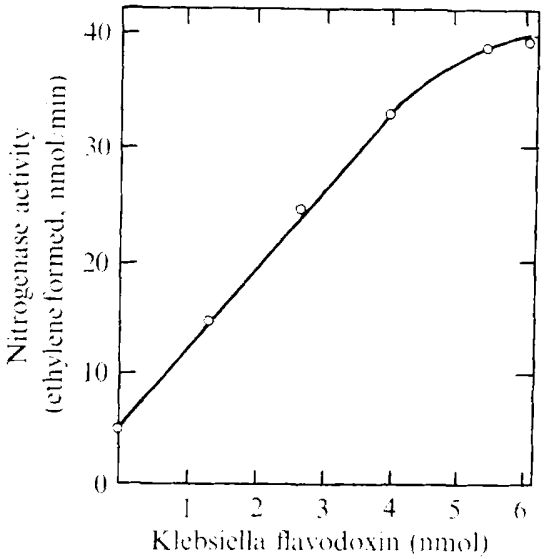

Fig. 5

Fig. 4. Absorption spectra of flavodoxin from $K$. pneumoniae. The flavodoxin was reduced to the semiquinone form by the addition, under anaerobic conditions, of microlitre quantities of $10 \mathrm{~mm}$ sodium dithionite. Insert, the complete spectrum of oxidized Klebsiella flavodoxin.

Fig. 5. Effectiveness of Klebsiella flavodoxin in coupling the reducing power of illuminated chloroplasts to $K$. pneumoniae nitrogenase. Reaction mixture as described in Fig. I, with $7.8 \mathrm{mg}$ of Klebsiella nitrogenase extract and the concentration of Klebsiella flavodoxin as indicated.

$\mathrm{B}$ and $\mathrm{D}$ ) indicates proteins with biological activity in the chloroplast-nitrogenase reaction. On several occasions fractions $\mathrm{C}$ and $\mathrm{D}$ eluted as a single band. After this chromatographic separation on DEAE-cellulose, these four fractions were concentrated and chromatographed separately on Sephadex G-50. After Sephadex G-50 chromatography, fractions A, B and C, while not homogeneous, appeared on gel electrophoresis to be free from other coloured proteins; fraction $\mathrm{D}$ was still a mixture of at least three different coloured proteins. Because the yield was low, purification of fraction $\mathrm{D}$ was not continued.

\section{Properties and biological activity of the Klebsiella electron carriers}

Fraction A was yellow and had the spectrum of a flavoprotein. It showed no electron carrier activity in the 'chloroplast-nitrogenase' assay or in the photoreduction of NADP by illuminated chloroplasts. Its biological activity is unknown.

That fraction B was also a flavoprotein was indicated by its optical spectrum (Fig. 4). The complete spectrum of the flavoprotein in the oxidized form has absorption maxima at 277,370 and $452 \mathrm{~nm}$, and is shown in the insert to Fig. 4. On the addition of small quantities of sodium dithionite, the flavodoxin was reduced to the blue semiquinone form, a species with a broad absorbance maximum at 580 to $620 \mathrm{~nm}$. Although not shown in this Figure, the addition of more dithionite reduced the blue semiquinone species to the colourless 


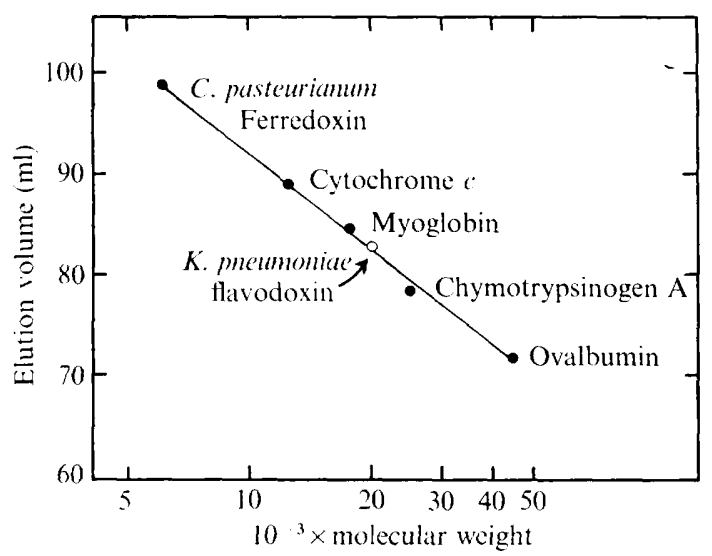

Fig. 6

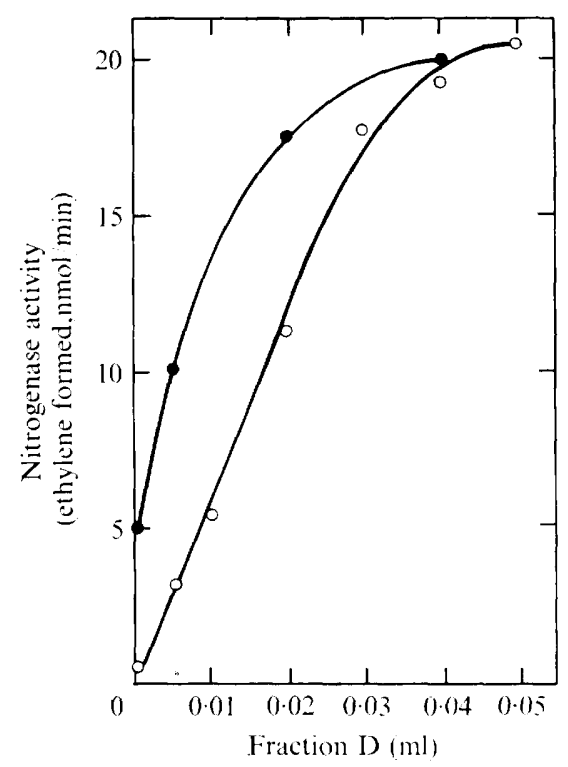

Fig. 7

Fig. 6. Molecular weight determination of Klebsiella flavodoxin by gel filtration. The protein markers $(5 \mathrm{mg}$ each except for $C$. pasteurianum ferredoxin which was $1 \mathrm{mg}$ ) were applied to a Sephadex G-100 (superfine) column $(\mathrm{I} \cdot 5 \times 80 \mathrm{~cm})$ equilibrated and eluted with $0.02 \mathrm{M}$-phosphate buffer $\mathrm{pH} 7.4,0.5 \mathrm{M}-\mathrm{NaCl}$ and $0.0 \mathrm{I} \mathrm{M}-2$-mercaptoethanol. The flavodoxin was applied and eluted separately. The flow rate was approx. $2 \cdot 2 \mathrm{ml} / \mathrm{h}$.

Fig. 7. Effectiveness of Klebsiella fraction $D$ in coupling the reducing power of illuminated chloroplasts to K.pneumoniae and $A$. vinelandii nitrogenases. Reaction mixture as in Fig I, with the volume of fraction $\mathrm{D}(1.4 \mathrm{mg}$ protein/ml) as indicated, and either $(O) A$. vinelandii nitrogenase extract, $7.5 \mathrm{mg}$ protein, or (๑) K. pneumoniae nitrogenase extract, $6.7 \mathrm{mg}$ protein (both had previously been treated with DEAE-cellulose to remove endogenous electron carriers).

hydroquinone (fully reduced) form. Some variation from one preparation of flavodoxin to another in the 370 to $452 \mathrm{~nm}$ absorbance ratio was observed. Although in these preparations (Fig. 4) the 370 to $452 \mathrm{~nm}$ absorbance ratio was slightly greater than one, in other flavodoxin preparations this ratio was slightly less than one. There is no immediately apparent explanation for this observation.

Fraction B coupled electron transfer between illuminated chloroplasts and Klebsiella nitrogenase (Fig. 5). The finding that this flavoprotein functions in the nitrogenase reaction suggests that fraction B is a Klebsiella flavodoxin, as only flavodoxins among the flavoproteins are known to reduce nitrogenase. There was not a sufficient amount of pure Klebsiella flavodoxin available to determine its extinction coefficient successfully; therefore, the extinction coefficient used to determine the flavodoxin concentration was that of free FMN (I $2 \cdot \mathrm{I} \mathrm{mM}^{-1} \mathrm{~cm}^{-1}$ at $\left.450 \mathrm{~nm}\right)$. Using this value probably underestimates the concentration of flavodoxin as the extinction coefficient of the other flavodoxins varies from about 8.5 to $10.5 \mathrm{~mm}^{-1} \mathrm{~cm}^{-1}$ at $450 \mathrm{~nm}$ (Hinkson \& Bulen, I967; Mayhew \& Massey, I969; Vetter \& Knappe, I97I ; Cusanovich \& Edmondson, I97I; Mayhew, I97I). Thus, while the flavodoxin concentrations shown in Fig. 5 may be low (I0 to I $5 \%$ ), the point to be emphasized here is that this Klebsiella flavoprotein does in fact couple to the nitrogenase and is effective at relatively low concentrations.

The molecular weight of Klebsiella flavodoxin was estimated to be 21000 \pm 1000 by the gel filtration method (Andrews, I965) on Sephadex G-I00 (superfine grade) using Clostridium 
Table 4. The synergistic effect of methyl viologen on azotoflavin- and Klebsiella flavodoxin-coupled nitrogenase activity

The reaction mixture and conditions of assay were similar to those described for Fig. I with DEAE-treated Azotobacter extract $(5.9 \mathrm{mg}$ protein) as the source of nitrogenase, illuminated chloroplasts $(0.28 \mathrm{mg}$ chlorophyll) as the source of reductant, and electron carriers as indicated.

$\begin{array}{lc}\quad \text { Addition } & \begin{array}{c}\text { Ethylene formed } \\ (\mathrm{nmol} / \mathrm{min})\end{array} \\ \text { Azotoflavin }(2 \mathrm{I} \cdot 5 \mu \mathrm{M}) & \mathrm{I} 5 \cdot 8 \\ \text { Methyl viologen }(0.67 \mu \mathrm{M}) & \mathrm{I} \cdot 5^{*} \\ \text { Azotoflavin }(2 \mathrm{I} \cdot 5 \mu \mathrm{M})+\text { methyl viologen }(0.67 \mu \mathrm{M}) & 78 \cdot 0 \\ & \\ \text { Klebsiella flavodoxin }(7 \cdot \mathrm{I} \mu \mathrm{M}) & 3 \cdot 0 \\ \text { Methyl viologen }(0.67 \mu \mathrm{M}) & \mathrm{I} 2 \cdot \mathrm{I} \\ \text { Klebsiella flavodoxin }(7 \cdot 1 \mu \mathrm{M})+\text { methyl viologen }(0.67 \mu \mathrm{M}) & 62 \cdot 0 \\ \text { None } & 0\end{array}$

* The rate of nitrogenase activity one observes with low concentrations of methyl viologen probably depends on how completely the endogenous electron carriers are removed from the Azotobacter extract (cf. Table 2; Yoch, 1972).

pasteurianum ferredoxin, cytochrome $c$, myoglobin, chymotrypsinogen and ovalbumin as standards (Fig. 6).

Klebsiella flavodoxin resembles azotoflavin (Hinkson \& Bulen, 1967; Benemann et al. 1969) in that it does not mediate the photochemical reduction of $\mathrm{NADP}^{+}$by ferredoxin-free chloroplast fragments at low concentrations under aerobic conditions. Klebsiella flavodoxin further resembles azotoflavin (Yoch, 1972) in that catalytic concentrations of methyl viologen greatly increase its effectiveness as a link between the reducing power generated by spinach chloroplasts and DEAE-cellulose-treated Azotobacter nitrogenase (Table 4). The stimulatory effect of methyl viologen on azotoflavin- and Klebsiella flavodoxinmediated nitrogenase activity may be a phenomenon common to all flavodoxins.

Fraction $\mathrm{C}$ was a blue protein that showed a broad absorption peak with a maximum at $630 \mathrm{~nm}$. Although this protein spectrally resembles the copper-containing Pseudomonas blue protein (azurin) isolated by Horio (1958 $a, b)$, the Klebsiella blue protein differs in that it could not be reduced by ascorbate but was readily reduced to a colourless form by sodium dithionite. The fact that the Klebsiella blue protein was not reduced by ascorbate appears to make it unlike any of the known blue copper-containing proteins (see review by Malkin, 1973). The biological function of the Klebsiella blue protein is unknown.

Fraction $\mathrm{D}$ was brown in colour. Disc gel electrophoresis showed this fraction to be a combination of several different coloured proteins and therefore it had no distinct spectral characteristics. Klebsiella fraction D coupled the reducing power of illuminated chloroplasts equally well to the nitrogenases of Klebsiella and Azotobacter (Fig. 7). The low level of Klebsiella nitrogenase activity in the absence of added fraction D indicates that a small amount of endogenous electron carrier contaminated the Klebsiella nitrogenase extract. Like Klebsiella flavodoxin, fraction D did not function as a substitute for plant ferredoxin in the photoreduction of $\mathrm{NADP}^{+}$by chloroplast or blue-green algae fragments. The identity of the active electron transport component in fraction $\mathrm{D}$ is unknown. 


\section{DISCUSSION}

The restoration of pyruvate-supported nitrogenase activity in Klebsiella extracts by an extract prepared from glucose-fermenting E. coli cells and the greater efficiency of photoreduced $E$. coli flavodoxin in coupling to Klebsiella nitrogenase than to Azotobacter nitrogenase suggest that $K$. pneumoniae and $E$. coli may generate and transport electrons of low oxidation-reduction potential by a similar mechanism.

The predominant electron carrier in Klebsiella, as in E. coli (Vetter \& Knappe, 197I) appears to be the flavodoxin. However, unlike $E$. coli flavodoxin (Vetter \& Knappe, I97I), the one from Klebsiella does not substitute for plant ferredoxin in the reduction of NADP ${ }^{+}$ by illuminated chloroplasts. In this respect Klebsiella flavodoxin resembles a flavoprotein electron carrier from $A$. vinelandii called azotoflavin or, more recently, Azotobacter flavodoxin. Although van Lin \& Bothe (1972) reported that azotoflavin functions in this chloroplast reaction when high concentrations ( 100 to $200 \mu \mathrm{M}$ ) of the flavoprotein are used under strictly anaerobic conditions, I was unable to verify this claim. Similarly negative results were obtained with Klebsiella flavodoxin under these conditions.

The identity of the second electron carrier in Klebsiella, designated in this report as fraction $\mathrm{D}$, is not known; by analogy with $E$. coli, one might expect the active component to be a coliform ferredoxin. Whereas no biological activity was reported for $E$. coli ferredoxin (Vetter \& Knappe, 197I), Klebsiella fraction D does have one ferredoxin-like activity in that it reduces nitrogenase.

The significance of finding two electron carriers in Klebsiella, each capable of coupling reducing power to Klebsiella nitrogenase, is not understood at the present time. It may be that the pyruvate- and formate-coupled nitrogenase systems function specifically with one or another of these carriers. In Azotobacter (Benemann et al. 197I) and Rhizobium root nodule bacteriods (Wong, Evans, Klucas \& Russell, I97I), both a ferredoxin and a flavodoxin-like protein are required to couple electron transport between NADPH and the nitrogenase.

In one respect the Klebsiella nitrogenase system resembles that of the photosynthetic bacterium Chromatium, in that reducing power from illuminated chloroplasts does not couple to the nitrogenase unless exogenous ferredoxin is added to the reaction mixture (Yoch \& Arnon, 1970). In Chromatium the ferredoxin appears to be bound to the membranes, as detergent (Triton $\mathrm{X}-\mathrm{IOO}$ ) treatment greatly increases the yield of ferredoxin isolated from these cells (K. T. Shanmugam, personal communication). In untreated Chromatium extracts, electrons from illuminated chloroplasts presumably do not couple to the nitrogenase because the ferredoxin is inaccessibly bound to the bacterial photosynthetic membranes. In Klebsiella, the reducing power from chloroplasts coupled to the nitrogenase only after a prolonged freezing of the extract (see Table 4), suggesting that this process might be releasing electron carriers that were bound or complexed in such a way as to be previously inaccessible to the electrons from chloroplasts. Although the evidence is preliminary, it would appear that the electron carriers that couple to the nitrogenase of Klebsiella and Chromatium are not soluble, as they are in other nitrogen-fixing microorganisms.

I acknowledge R. C. Valentine's participation in demonstrating that an $E$. coli extract could reconstitute the pyruvate-driven nitrogenase activity in aged Klebsiella nitrogenase extracts (Table I). 


\section{REFERENCES}

ANDREws, P. (1965). The gel filtration behaviour of proteins related to their molecular weights over a wide range. Biochemical Journal 96, 595-606.

Benemann, J. R., Yoch, D. C., Valentine, R. C. \& Arnon, D. I. (1969). The electron transport system in nitrogen fixation by Azotobacter. I. Azotoflavin as an electron carrier. Proceedings of the National Academy of Sciences of the United States of America 64, 1079-1086.

Benemann, J. R., Yoch, D. C., Valentine, R. C. \& Arnon, D. I. (I97I). The electron transport system in nitrogen fixation by Azotobacter. III. Requirements for NADPH-supported nitrogenase activity. Biochimica et biophysica acta 226, 205-2 I 2.

Biggins, D. R. \& Kelly, M. (1970). Interaction of nitrogenase from Klebsiella pneumoniae with ATP or cyanide. Biochimica et biophysica acta 205, 288-299.

Bulen, W. A., Burns, R. C. \& LeComte, J. R. (I965). Nitrogen fixation: hydrosulfite as electron donor with cell-free preparations of Azotobacter vinelandii and Rhodospirillum rubrum. Proceedings of the National Academy of Sciences of the United States of America 53, 532-539.

BURRIS, R. H. (197I). Fixation by free-living micro-organisms: enzymology. In The Chemistry and Biochemistry of Nitrogen Fixation, pp. 105-I60. Edited by J. R. Postgate. New York: Plenum Press.

Cusanovich, M. A. \& Edmondson, D. E. (1971). The isolation and characterization of Rhodospirillum rubrum flavodoxin. Biochemical and Biophysical Research Communications 45, 327-336.

DilworTH, M. J. (I966). Acetylene reduction by nitrogen-fixing preparations from Clostridium pasteurianum. Biochimica et biophysica acta 127, 285-294.

Dixon, R. A. \& Postgate, J. R. (197I). Transfer of nitrogen-fixation genes by conjugation in Klebsiella pneumoniae. Nature, London 234, 47-48.

Dixon, R. A. \& Postgate, J. R. (I972). Genetic transfer of nitrogen fixation from Klebsiella pneumoniae to Escherichia coli. Nature, London 237, I02-103.

Eady, R. R., Smith, B. E., Cook, K. A. \& Postgate, J. R. (1972). Nitrogenase of Klebsiella pneumoniae. Purification and properties of the component proteins. Biochemical Journal 128, 655-675.

Hamilton, P. B. \& Wilson, P. W. (1955). Nitrogen fixation by Aerobacter aerogenes. A. I. Virtanen Homage Volume, Biochemistry of Nitrogen, Annales Academiae scientiarum fennicae, Series A II 6o, I39-150.

Hardy, R. W. F., Holsten, R. D., Jackson, E. K. \& Burns, R. C. (1968). The acetylene-ethylene assay for $\mathrm{N}_{2}$ fixation: laboratory and field evaluation. Plant Physiology 43, I185-1207.

Hinkson, J. W. \& Bulen, W. A. (1967). A free radical flavoprotein from Azotobacter. Journal of Biological Chemistry 242, 3345-335I.

Horio, T. (1958a). Terminal oxidation system in bacteria. I. Purification of cytochromes from Pseudomonas aeruginosa. Journal of Biochemistry 45, 195-205.

Horio, T. (1958b). Terminal oxidation system in bacteria. II. Some physical and physiological properties of purified cytochromes of Pseudomonas aeruginosa. Journal of Biochemistry 45, 267-279.

KLuCAS, R. (1972). Nitrogen fixation by Klebsiella grown in the presence of oxygen. Canadian Journal of Microbiology 18, I845-I850.

Koch, B., Wong, P., Russell, S. A., Howard, R. \& Evans, H. J. (1970). Purification and some properties of a non-haem iron protein from the bacteriods of soya-bean (Glycine max Merr) nodules. Biochemical Journal I18, 773-78I.

VAn Lin, B. \& Bothe, H. (1972). Flavodoxin from Azotobacter vinelandii. Archiv für Mikrobiologie 82, I55-I 72 .

LuRIA, S. E. \& Burrous, J. W. (1957). Hybridization between Escherichia coli and Shigella. Journal of Bacteriology 74, 46I-476.

MAHL, M. C. \& Wilson, P. W. (I968). Nitrogen fixation by cell-free extracts of Klebsiella pneumoniae. Canadian Journal of Microbiology 14, 33-38.

Mahl, M. C., Wilson, P. W., Fife, M. A. \& EWING, W. H. (1965). Nitrogen fixation by members of the tribe Klebsielleae. Journal of Bacteriology 89, 1482-1487.

MaLKIN, R. (1973). The copper-containing oxidases. In Inorganic Biochemistry, vol. 2, pp. 689-709. Edited by G. I. Eichhorn. New York: Elsevier.

Matsumoto, H. \& TAZAKI, T. (1970). Genetic recombination in Klebsiella pneumoniae. An approach to genetic linkage mapping. Japanese Journal of Microbiology 14, I29-I40.

MAYHew, S. G. (197I). Properties of two clostridial flavodoxins. Biochimica et biophysica acta 235, 276-288.

Mayhew, S. G. \& Massey, V. (1969). Purification and characterization of flavodoxin from Peptostreptococcus elsdenii. Journal of Biological Chemistry 244, 794-802. 
MCSwAIN, B. D. \& ARnon, D. I. (1968). Enhancement effects and the identity of the two photochemical reactions of photosynthesis. Proceedings of the National Academy of Sciences of the United States of America 6r, 989-996.

PENGRA, R.M.(1964). A survey of some cultures of the genus Aerobacter for nitrogen fixation. Bacteriological Proceedings, p. 9 (abstract).

SCHöLlHORN, R. \& BURRIS, R. H. (1966). Study of intermediates in nitrogen fixation. Federation Proceedings 25, 7 IO (abstract).

Silver, W. S., Centifanto, Y. M. \& Nicholas, D. J. D. (1963). Nitrogen fixation by the leaf-nodule endophyte of Psychotria bacteriophila. Nature, London 199, 396-397.

Streicher, S., Gurney, E. \& Valentine, R. C. (197I). Transduction of the nitrogen-fixation genes in Klebsiella pneumoniae. Proceedings of the National Academy of Sciences of the United States of America 68, II74-II77.

VetTer, H., Jun. \& KnAPPe, J. (197I). Flavodoxin and ferredoxin of Escherichia coli. Hoppe-Seyler's Zeitschrift für physiologische Chemie 352, 433-446.

Wong, P., Evans, H. J., Klucas, R. \& Russell, S. (1971). Investigations into the pathway of electron transport to the nitrogenase from nodule bacteroids. In Plant and Soil, special edition, Biological Nitrogen Fixation, pp. 525-543. Edited by T. A. Lie and E. G. Mulder. The Hague: Martinus Nijhoff.

Wood, W. A. (196I). Fermentation of carbohydrates and related compounds. In The Bacteria, vol. 2, pp. 59-I49. Edited by I. C. Gunsalus and R. Y. Stanier. New York: Academic Press.

YoCH, D. C. (1972). The electron transport system in nitrogen fixation by Azotobacter. IV. Some oxidationreduction properties of azotoflavin. Biochemical and Biophysical Research Communications 49, 335-342.

Yoсн, D. C. (1973). Purification and properties of two ferredoxins from the nitrogen-fixing bacterium Bacillus polymyxa. Archives of Biochemistry and Biophysics 158, 633-640.

Yoch, D. C. \& ARnon, D. I. (1970). The nitrogen fixation system of photosynthetic bacteria. II. Chromatium nitrogenase activity linked to photochemically generated assimilatory power. Biochimica et biophysica acta 197, I80-184.

Yoch, D. C., Benemann, J. R., Arnon, D. I., Valentine, R. C. \& Russell, S. A. (1970). An endogenous electron carrier for the nitrogenase system of Rhizobium bacteroids. Biochemical and Biophysical Research Communications 38, 838-842.

Yoch, D. C., Benemann, J. R., Valentine, R. C. \& Arnon, D. I. (I969). The electron transport system in nitrogen fixation by Azotobacter. II. Isolation and function of a new type of ferredoxin. Proceedings of the National Academy of Sciences of the United States of America 64, 1404-14IO.

Yoch, D. C. \& Pengra, R. M. (1966). Effect of amino acids on the nitrogenase system of Klebsiella pneumoniae. Journal of Bacteriology 92, 61 8-622. 